heights and many other situations. Such phobias are largely unrelated to more generalised anxiousness. There are some common features with the shakiness and lack of confidence that often afflicts musicians and other performers." ${ }^{\circ} \mathrm{He}$ said anti-anxiety drugs could have some benefit adding, "The very well proven treatment for phobic anxiety is cognitive behavioural treatment usually supervised by a psychologist."

\section{Early evidence}

Three hundred and forty years earlier another bell ringer described his fear that the bell or the church tower would fall on top of him. John Bunyan wrote: "I began to think how if one of the Bells should fall ... but then it came into my head, how if the Steeple itself should fall, and this

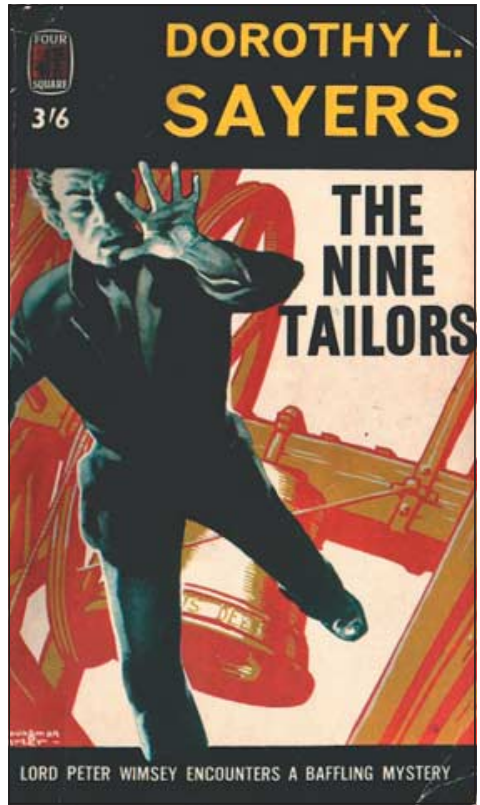

writer Dorothy L Sayers's "graphic detail of the vibration and deafening sound" of bell ringing in her 1934 novel The Nine Tailors.

While it would be lovely to let Bunyan or Sayers have the last word on ringing vertigo, perhaps the best epilogue comes from a letter in Ringing World this month. ${ }^{9}$ An affected ringer from Petworth in West Sussex wrote to say that the night after seeing a specialist for treatment of an unrelated condition, she gradually realised that she was not experiencing any of the usual vertigo symptoms. "It was the same for Sunday ringing, and subsequently six weddings." She wrote, "I took no pills and the treatment involved very gentle muscle manipulation." What was the unrelated complaint? "The dreaded hot flushes. I haven't had any of those either!"

thought, (it may fall for ought I know) would, when I stood and looked on, continually so shake my mind, that I durst not stand at the Steeple door any longer, but was forced to fly for fear it should fall upon my head." Bunyan's experience at Elstow church was cited this year as evidence that ringing vertigo was not new; it had just not been properly discussed before, Ringing World editor Robert Lewis told the Guardian, "perhaps because the sufferers feared they might be ridiculed."

The Times devoted a leading article to ringing vertigo, calling for "more enthusiastic support for our campanologists so that aspirants are everywhere queuing to work with Quasimodo" and citing the crime
And so ringing vertigo vanished, almost as unexpectedly as it had first arisen in the pages of Ringing World seven months earlier.

Competing interests: None declared.

1 Mottershead J. Ringing vertigo. Ringing World 2005 May 6:426.

Camp J. Ringing vertigo. Ringing World 2005 May 20:473.

Sherlaw-Johnson R. Ringing vertigo-another angle. Ringing World 2005 June 10:548.

Bennett R. Ringing vertigo. Ringing World 2005 July 1:618.

Wild J. A young sufferer. Ringing World 2005 July 29:717.

Wild J. A young sufferer. Ringing World 2005 July 29:717.
Mayou R. "Ringing vertigo." Ringing World 2005 July 15:666.

Mayou R. "Ringing vertigo." Ringing World 2005 July 15:666.
Bunyan J. Grace abounding to the chief of sinners. New York: Oxford Univer-

Morris M. Church ringers suffer spate of panic attacks. Guardian $2005 \mathrm{Jul} 4$. 9 Major H. Vertigone! Ringing World 2005 Dec 2:1162. Bunyan J. Grace abou
sity Press Inc, 1998.

\title{
Barbering in mice: a model for trichotillomania
}

\author{
Biji T Kurien, Tim Gross, R Hal Scofield
}

Barbering (excessive grooming causing hair loss) in mice resembles trichotillomania (uncontrollable hair pulling) in humans in several respects and may be a useful model of trichotillomania, especially for investigating the complex genetic and environmental interactions

Our interest in systemic lupus erythematosus led us to develop an animal model of lupus by immunising rabbits or mice with peptides that are targets of autoimmune sera from people with lupus. Animals immunised with these peptides developed autoimmunity to the entire Ro ribonucleoprotein as well as to other autoantigens..$^{1-3}$ During this study, we observed the loss of facial hair in a group of five experimental mice, possibly a sign of alopecia, a symptom of lupus. When we observed the characteristics of the hair loss and the fact that one of the mice had not lost her facial hair whereas the other four had, we realised that this was a clear case of "barbering."

\section{Barbering in mice}

Fur and whisker trimming by laboratory mice is referred to as "barbering." Laboratory mice housed in groups are frequently found with their facial hair and whiskers removed (figure). In one study facial alopecia was found in three of four adult female Fisher 344 rats that shared a cage for two months. ${ }^{4}$ The hairless areas were non-pruritic and without any association with pathogenic skin bacteria, dermatophytes, or ectoparasites. The authors found that when the unaffected rat was placed with a different set of rats, facial alopecia became evident in those animals within six days, and the hair of the original cagemates grew back within 21 days. Thus the alopecia was found to be caused by a dominant female "barber."

In another study the barbering process was videotaped in pairs of C57BL6 mice containing a dominant barber and a passive recipient, which showed that dominant mice were responsible for barbering the hair of the recipient (the "Dalila effect").
Arthritis and

Immunology Program,

Oklahoma Medical Research Foundation, $825 \mathrm{NE} 13$ th Street, Oklahoma City, OK 73104, USA

Biji T Kurien senior research scientist

Tim Gross senior research assistant

R Hal Scofield associate member Correspondence to: B T Kurien biji-kurien@ omrf.ouhsc.edu

BMJ 2005;331:1503-5 
Barbering occurred only during mutual grooming, when one member of a mouse pair removed the whiskers of the other by grasping individual whiskers with the incisors and plucking them out. The recipients seemed passive in accepting the presumably painful procedure and even pursued the barber for further grooming. It was found that the barbers were heavier than the recipients, but with no apparent difference in brain weight. ${ }^{5}$ Barbering occurs only occasionally in group housed laboratory mice, but occurs almost invariably in the A2G strain of mice. ${ }^{6}$ This tendency progresses with age in these animals. Over three quarters of cages with two or three mice have one or more active barbers by the time the mice are 60 days old.?

Diseases in animals that develop spontaneously in a limited subpopulation can serve as models of human disease as they provide ways to investigate the interaction of a wide range of environmental and biological processes. In contrast, the aetiology of experimentally induced animal models is inherently fixed. ${ }^{8}$ The abnormal barbering seen in mice resembles the compulsive hair plucking in humans known as trichotillomania and could serve as an animal model of this disease because the barbering mice pluck focused areas of hair, barbering is female biased, onset of barbering occurs during puberty, and the aetiological factors included genetic background and reproductive status. Trichotillomania also has important similarities with an avian disorder known as feather picking in terms of behaviour and proposed aetiologies. ${ }^{9}$

\section{What is trichotillomania?}

Excessive pathological grooming in humans is a neuropsychiatric condition associated with obsessivecompulsive disorder. ${ }^{10}$ Trichotillomania, a disorder involving the uncontrollable pulling of one's own hair that can lead to baldness and loss of eyebrow hair, is often characterised as falling within the spectrum of obsessive-compulsive disorders. However, in spite of overlapping phenomenology, there are important differences. Firstly, there is the absence of obsessive rumination in trichotillomania. Hair pulling in trichotillomania is not in response to obsessive thoughts (such as worry about harm to others or self) but to an irresistible urge coupled with the promise of gratification associated with pulling of hair, in contrast to compulsions in obsessive-compulsive disorder. ${ }^{11}$ Secondly, the ego-dystonic compulsive act is absent,

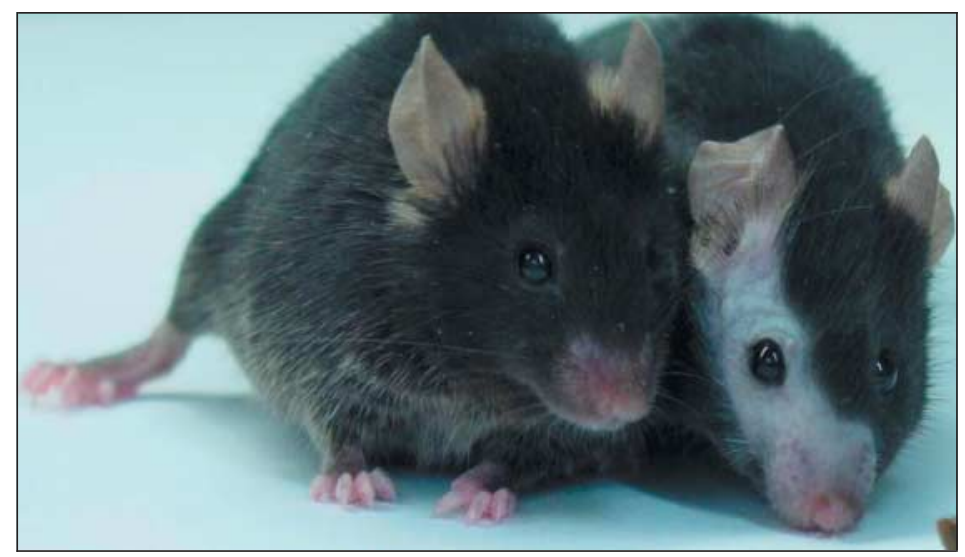

Barbering in mice: the "barber" is on the left and the "recipient" on the right and individuals tend not to substitute other compulsive rituals after prevention of hair pulling. Thus, patients with trichotillomania usually present only with hair pulling without evolution to non-self injurious compulsive rituals, unlike patients with obsessivecompulsive disorder, whose symptoms change over time in terms of focus and severity (such as from checking locks, stoves, appliances, etc, to washing hands)..$^{12} 13$

Trichotillomania, first described in $1889,{ }^{14}$ is classified in the Diagnostic and Statistical Manual of Mental Disorders, fourth edition (DSM-IV) as an "impulsecontrol disorder not elsewhere specified." ${ }^{15}$ The prevalence of trichotillomania is $0.6-1.6 \%$ when DSM-IV criteria are used. ${ }^{16}$ The number of hairs extracted, time spent in pulling hair, and the pattern of pulling vary considerably among sufferers. Those who engage in these kinds of activity also indulge in other repetitive body focused behaviours such as nail biting, tongue chewing, head banging, and cheek chewing. ${ }^{17} 18$ Hair pulling has also been diagnosed in early childhood, and this has been conceptualised as an anxiety disorder. $^{19}$

\section{A genetic model for trichotillomania}

Obsessive-compulsive behaviour disorder in humans is often characterised by excessive behaviours dealing with cleanliness, including grooming. Mice homozygous for a loss of function mutation in the Hoxb8 gene show excessive pathological grooming that leads to removal of hair from their own body as well as barbering cagemates and self infliction of wounds in groomed areas. ${ }^{20}$ Hoxb8 is a member of the mammalian Hox (Homeo-box-containing) complex, comprising a group of 39 transcription factors. The Hox genes function in enabling embryonic development, hair formation in adult mice, and maturation of breast tissue in female mice. ${ }^{20}$

In the case of barbering in mice two agents are needed, the dominant barber and the passive recipient-whereas in human trichotillomania these roles are ostensibly combined. While those who pull hair may be a clinically heterogeneous group there is some consensus that those with trichotillomania fall into one of two categories-focused (those who experience mounting anxiety before hair pulling and obtain subsequent relief) or automatic (those who pull their hair when distracted). ${ }^{21}$ In the case of barbering the recipient mouse that pursues the barber is analogous to the automatic variant, since the regrowth of hair (and, by inference, lack of hair pulling) in the barber's absence is more or less incompatible with the drive to relieve tension that forms the basis of focused trichotillomania. However, individually housed Hoxb8 mutants groom themselves excessively and have large bald patches on their ventral and lateral surfaces, ${ }^{20}$ thus showing similarity to trichotillomania. All Hoxb8 mutants have shown normal reactions to heat, cold, pain, and pressure. They do not differ from normal mice in most behaviours except for grooming, hair pulling, and self mutilation.

The excessive grooming behaviour linked to the loss of Hoxb8 function is clinically interesting on account of its possible relation to the aetiology of human trichotillomania, especially because the mouse 


\section{Summary points}

Trichotillomania is an "impulse-control disorder" in humans, characterised by repetitive stereotypical hair pulling from different areas

Barbering in mice can serve as an animal model of trichotillomania

Mice homozygous for a loss of function mutation in Hoxb8 gene (involved in grooming behaviour) display clinical signs of trichotillomania

Studies are needed to see if people with trichotillomania have the same mutation and whether prescription drugs that ameliorate trichotillomania can cut back grooming in Hoxb8 mice

and human pathologies are similar. Trichotillomania may arise as a result of the misregulation of an innate self grooming behaviour that results in excessive repetition. It would be interesting to find out whether subsets of human patients with trichotillomania have defects in the Hoxb8 gene or in the paralogous family members Hoxc8 and Hoxd8.

We thank Judith A James for supplying the mice shown in the photograph and Yaser Dorri for his help with the photography. Contributors: Animal immunisation studies were carried out by BTK and RHS with TG's assistance. The manuscript was written by BTK and approved by RHS and TG.

Funding: This work was supported by NIH grant ARO1844 awarded to RHS and by funding from the Oklahoma Center for the Advancement of Science and Technology to RHS and BTK. Competing interests: None declared.

Ethical approval: The animal immunisation experiments described in the manuscript were approved by the Institutional Review Board.
1 Scofield RH, Henry WE, Kurien BT, James JA, Harley JB. Immunization with short peptides from the sequence of the systemic lupus erythematosus-associated 60-kDa Ro autoantigen results in anti-Ro ribonucleoprotein autoimmunity. J Immunol 1996;156:4059-66.

2 Scofield RH, Kaufman KM, Baber U, James JA, Harley JB, Kurien BT. Immunization of mice with human 60-kd Ro peptides results in epitope spreading if the peptides are highly homologous between human and mouse. Arthritis Rheum 1999:42:1017-24.

3 Scofield RH, Pierce PG, James JA, Kaufman KM, Kurien BT. Immunization with peptides from $60 \mathrm{kDa}$ Ro in diverse mouse strains. Scand J Immunol 2002;56:477-83.

4 Bresnahan JF, Kitchell BB, Wildman MF. Facial hair barbering in rats. Lab Anim Sci 1983;33:290-1.

5 Sarna JR, Dyck RH, Whishaw IQ. The Dalila effect: C57BL6 mice barber whiskers by plucking. Behav Brain Res 2000;108:39-45.

6 Strozik E, Festing MF. Whisker trimming in mice. Lab Anim 1981;15:30912.

7 Van den Broek FA, Omtzigt CM, Beynen AC. Whisker trimming behaviour in A2G mice is not prevented by offering means of withdrawal from it. Lab Anim 1993;27:270-2.

8 Garner JP, Weisker SM, Dufour B, Mench JA. Barbering (fur and whisker trimming) by laboratory mice as a model of human trichotillomania and obsessive-compulsive spectrum disorders. Comp Med 2004;54:216-24.

9 Ordnick PS, Thyer BA, Ritchie BW. Feather picking disorder and trichotillomania: an avian model of human psychopathology. J Behav Ther Exp Psychiatry 1994;25:189-96.

10 Reilly CE. Disruption of Hoxb8 gene leads to obsessive grooming behavior. J Neurol 2002;249:499-501.

11 Stein DJ, Simeon D, Cohen LJ, Hollander E. Trichotillomania and obsessive-compulsive disorder. J Clin Psychiatry 1995;56(suppl 4):28-34

12 Lochner C, Seedat S, du Toit PL, Nel DG, Niehaus DJ, Sandler R, et al. Obsessive-compulsive disorder and trichotillomania: a phenomenological comparison. BMC Psychiatry 2005;5:2.

13 Swedo SE, Leonard HL, Rapoport JL. Childhood-onset obsessive compulsive disorder. Psychiatr Clin North Am 1992;15:767-75.

14 Alsafwah S, Alzein M. Small bowel obstruction due to trichobezoar: role of upper endoscopy in diagnosis. Gastrointest Endosc 2000;52:784-6.

15 Diagnostic and statistical manual of mental disorders. 4 th ed. Washington DC: American Psychiatric Press, 1994:618.

16 O'Sullivan RL, Mansueto CS, Lerner EA, Miguel EC. Characterization of trichotillomania. A phenomenological model with clinical relevance to obsessive-compulsive spectrum disorders. Psychiatr Clin North Am 2000;23:
on obsessive-
$587-604$.

17 Simeon D, Cohen LJ, Stein DJ, Schmeidler J, Spadaccini E, Hollander E. Comorbid self-injurious behaviors in 71 female hair-pullers: a survey study. J Nerv Ment Dis 1997;185:117-9.

18 Bouwer C, Stein DJ. Trichobezoars in trichotillomania: case report and literature overview. Psychosom Med 1998;60:658-60.

19 Wright HH, Holmes GR. Trichotillomania (hair pulling) in toddlers. Psychol Rep 2003;92:228-30.

20 Greer JM, Capecchi MR. Hoxb8 is required for normal grooming behavior in mice. Neuron 2002;33:23-34.

21 Du Toit PL, van Kradenburg J, Niehaus DJ, Stein DJ. Characteristics and phenomenology of hair-pulling: an exploration of subtypes. Compr Psychiatry 2001;42:247-56.

\title{
Harry Potter casts a spell on accident prone children
}

\author{
Stephen Gwilym, Dominic P J Howard, Nev Davies, Keith Willett
}

In the infancy of this millennium two things are certain: children injure themselves on the latest "craze" and children will (probably) read the Harry Potter books. Previous reports have highlighted the impact of emerging crazes such as inline skating and microscooters, with attention being drawn to potential accident prevention and emerging patterns of injury.

One modern craze is the Harry Potter series of books and films. In the United Kingdom sales of the latest Harry Potter book, The Half-Blood Prince, are estimated to reach four million, with around three million volumes being sold in the first week.

Given the lack of horizontal velocity, height, wheels, or sharp edges associated with this particular craze we were interested to investigate the impact the Harry Potter books had on children's traumatic injuries during the peak of their use.

\section{Methods and results}

We undertook a retrospective review of all children aged 7-15 who attended our emergency department with musculoskeletal injuries over the summer months of a three year period. Weekend admissions were counted as those occurring between 8 am on Saturday and 8 am on Monday. The age range was based on that of reading competence on the advice of an educationalist.

The launch dates of the two most recent Harry Potter books-The Order of the Phoenix ${ }^{1}$ and The Half-Blood Prince ${ }^{2}$-were Saturday 21 June 2003 and Saturday 16 July 2005 . We compared the numbers of admissions for these weekends with those for surrounding summer weekends and those dates in previous years.
Department of Orthopaedic Trauma Surgery, John Radcliffe Hospital, Oxford OX3 9DU Stephen Gwilym specialist registrar Dominic P J Howard senior house officer Nev Davies specialist registrar Keith Willett consultant

Correspondence to: S Gwilym s_gwilym@ yahoo.com

BMJ 2005;331:1505-6 